\title{
Effects of Irrigation with Treated Wastewater or Well Water on the Nutrient Contents of Two Alfalfa (Medicago Sativa L.) Cultivars in Riyadh, Saudi Arabia
}

\author{
Walid Soufan 1,*D, Mohammad K. Okla ${ }^{2}$ and Abdullah A. Al-Ghamdi ${ }^{2}$ \\ 1 Plant Production Department, College of Food and Agriculture Sciences, King Saud University, \\ P.O. Box 2460, Riyadh 11451, Saudi Arabia \\ 2 Botany and Microbiology Department, College of Science, King Saud University, P.O. Box 2455, \\ Riyadh 11451, Saudi Arabia; maloklaa@ksu.edu.sa (M.K.O.); abdalghamdi@ksu.edu.sa (A.A.A.-G.) \\ * Correspondence: wsoufan@ksu.edu.sa
}

Received: 8 October 2019; Accepted: 5 November 2019; Published: 8 November 2019

\begin{abstract}
Water scarcity has greatly increased the need for research into alternative irrigation methods. Irrigation with treated wastewater (TW) is considered an important alternative in terms of reducing our dependence upon groundwater and freshwater. In this study, we examined the effects of irrigation with TW on the nutrient contents of two alfalfa cultivars and compared them with the nutrient contents of plants irrigated with well water (WW). The two cultivars (Alhassawy-a local cultivar and CUV101) were cultivated from 2013 to 2015 and sampled twice. For both cultivars and in both sampling periods, irrigation with TW significantly affected the macronutrient and micronutrient contents of alfalfa tissues. Plants irrigated with TW had higher K and Ca contents, but lower N, $\mathrm{P}$, and $\mathrm{Mg}$ contents. No significant variation in $\mathrm{S}$ content was noted between plants irrigated with WW and TW. Furthermore, cultivar and cutting time had significant effects on nutrient contents, and these variables interacted with the effect of the water type used for irrigation. However, before TW can be regularly used in irrigation processes, further long-term studies are needed that consider the variations in water treatment efficiency and differences between cultivated sites in addition to the crop being irrigated with TW.
\end{abstract}

Keywords: alfalfa; forage crops; water treatment

\section{Introduction}

Irrigation with treated wastewater (TW) is already employed in many countries, and the number of countries using TW in irrigation is increasing. In particular, less developed countries in Asia and Africa have been adopting the practice [1-4]. Treated wastewater can be used in many sites depending on water reliability, degree of treatment, and the environmental impact of TW application. Irrigation with TW can be used for industrial fields, large green areas, municipal plants in the streets, landscapes, industrial crops, or forage crops, depending on the degree of wastewater treatment [5,6]. Moreover, TW can be used to irrigate energy crops [7]. In Saudi Arabia, treated sewage is used to irrigate municipal plants in the streets, and this has now been expanded to include crops in some farms [8,9] under strict government supervision and control. In light of the scarcity of water sources in arid and semi-arid areas, and in order to conserve groundwater, it is important to look into other irrigation practices such as the use of TW to produce forage to feed livestock [10], such as alfalfa. 
Several studies have examined the effects of irrigation with TW and have reported various effects ranging from positive to moderate and negative. The main positive effects of irrigation with TW include enhanced production and increases in the macronutrient and micronutrient contents of plant tissues [11]. Further, the positive environmental effects include improved soil fertility [12], reduced discharge of residual waters [13], and reduced groundwater uptake [14]. On the contrary, negative effects include the presence of contaminants that may enter the soil, groundwater, and plant tissues, as well as the presence of pathogens, heavy metals [14,15], pollutants (e.g., pharmaceuticals) [16], and pesticides in the water [17].

Alfalfa is considered to have been the first forage crop in the world, and the first in Saudi Arabia. Furthermore, it is the most cultivated forage crop in terms of cultivated area and quantity produced [18]. Alfalfa is classified as one of the most water-consuming crops during its growing season [19]. As a perennial crop, it is cultivated for over 5 years, and soil tillage is prevented during this period as the crop residues remain on the soil surface. Treated wastewater is a source of irrigation water and nutrients for plants [4,8]; however, it may contain bacteria and elements that are toxic to soils and plants [20-22]. In most cases, alfalfa is used in its dehydrated form to feed cattle, which inherently limits the risk of pathogen transfer via TW [23]. Furthermore, alfalfa can tolerate a moderately low-quality water supply [24].

Water scarcity is one of the most crucial problems currently being faced by the world, not only in arid and semi-arid regions but also in other parts of the world where water is more readily available. The main issues pertain to water quality and to sustainable water use that will not affect future generations. Therefore, methods of sustainable water use and the application of sustainability principles in water management have become some of the most important areas of research worldwide. Saudi Arabia has been dramatically affected by the global freshwater shortage, as many farms and agricultural projects have consumed huge amounts of deep non-renewable freshwater reserves and have experienced a gradual increase in well water salinity that has resulted in high levels of topsoil salination. Consequently, to stop the depletion of non-renewable freshwater resources, the Saudi cabinet has issued decrees (no. 66 dated 08/12/2015 and no. 39 dated 18/10/2016) to ban the cultivation of crops with low value and high water demand, such as wheat and forage crops including alfalfa [25]. Therefore, it has become crucial to find alternative irrigation methods and water resources.

It remains unclear whether TW is safe to be used in the irrigation of food and forage crops, mainly because of the risk of contamination with heavy metals that might transfer to the food chain. However, arid and semi-arid areas need alternative ways of irrigation to cope with water scarcity prevalence in these areas. One of the major barriers preventing the usage of TW in irrigation is the lack of social acceptance and belief, especially among farmers, in its beneficial effects [26-28]. Increasing farmers' awareness about the benefits as well as risks resulting from irrigation with wastewater could help in overcoming this problem. However, such a task needs more accurate and robust analysis of the risks and hazards or benefits associated with irrigation using TW. Therefore, further studies are needed to assess and clarify the risks associated with using TW in irrigation of food and forage crops and, thus, provide the required information for farmers and decision makers to help in increasing the adoption of TW in irrigation of food and forage crops. Especially, the presence of heavy metals is considered as the main limitation factor of using TW in irrigation. Translocation of heavy metals in alfalfa plants irrigated with TW needs more investigation considering different kinds of heavy metals. In the current study, we examined the concentrations of different heavy metals in alfalfa tissues over two seasons, aiming to analyze the effects of irrigation with TW on the nutrient contents of two alfalfa cultivars and measure the accumulation of harmful or toxic elements in the plants at the start and end of growing. The results of this study will help in providing the required information regarding the benefits and risks associated with irrigating alfalfa crops using TW for farmers and decision makers. 


\section{Materials and Methods}

\subsection{Experimental Design}

In this study, we examined the effects of irrigation with TW on alfalfa nutrient contents and compared them with plants irrigated with well water (WW). The experiment was conducted at the Dirab Agricultural Research and Experiment Station $\left(24^{\circ} 25^{\prime} 34.43^{\prime \prime} \mathrm{N}, 46^{\circ} 39^{\prime} 10.86^{\prime \prime}\right.$ E, $571 \mathrm{~m}$ a.s.1.), College of Food and Agriculture Science, King Saud University (KSU), Riyadh, Saudi Arabia, from 2013 to 2015. Seeds of two alfalfa cultivars (Alhassawy-a local cultivar and CUV101) were obtained from the College of Food and Agriculture Science, KSU. Well water was obtained from a well that is used for irrigation in the Dirab Agricultural Research and Experiment Station, while the TW was obtained from a sewage treatment plant in Riyadh. This treatment plant applies tertiary treatment procedures to wastewater. The treated water is transferred to the farms surrounding the treatment plant via a pipeline network starting from the plant and ending in the farms. Therefore, our experiment was receiving the water daily from the treatment plant via such a pipeline network without any special means of transportation or storage.

The experiment was carried out in a split-plot design, with the cultivar as the main plot and the irrigation type as the split plot factor, with three replicates for each treatment. Seeds of the two studied cultivars were planted in plots $(3 \times 4 \mathrm{~m})$ on 10 November 2013 , with $15 \mathrm{~cm}$ spacing between lines. The seeding rate was $40 \mathrm{~kg}$ seeds $\mathrm{ha}^{-1}$. All irrigation and fertilization processes were carried out according to the standards followed by the farmers in the study area as recommended by the Ministry of Environment, Water and Agriculture of Saudi Arabia (https://www.mewa.gov.sa/en/). In brief, TW reached our experimental site via the pipeline network already installed by the sewage treatment in Riyadh. All the plots were irrigated using surface irrigation methods once a week in winter and twice a week in the summer season until reaching field capacity. Prior to cultivation, plots were fertilized with $120 \mathrm{~kg} \mathrm{ha}^{-1}$ diammonium phosphate (DAP; $18 \mathrm{~N}, 46 \mathrm{P}_{2} \mathrm{O}_{5}$ ). After sowing, fertilizers were applied three times a year, after each harvest, with $120 \mathrm{~kg} \mathrm{ha}^{-1} \mathrm{DAP}, 50 \mathrm{~kg} \mathrm{ha}^{-1}$ urea $(50 \mathrm{~N}) \mathrm{and} \mathrm{kg} \mathrm{ha}^{-1}$ potassium sulfate $\left(\mathrm{K}_{2} \mathrm{SO}_{4} ; 50 \mathrm{~K}_{2} \mathrm{O}, 18 \mathrm{~S}\right)$. Weeds were removed manually as needed.

\subsection{Soil and Water Analysis}

Water samples were analyzed in the laboratories of KSU and the Ministry of Environment, Water and Agriculture in Saudi Arabia before starting the experiment. Physical parameters including $\mathrm{pH}$, electrical conductivity (EC), and total dissolved solids (TDS) were examined, in addition to the contents of several nutrients and heavy metals ( $, \mathrm{P}, \mathrm{K}, \mathrm{Ca}, \mathrm{Mg}, \mathrm{Na}, \mathrm{Fe}, \mathrm{Cu}, \mathrm{Zn}, \mathrm{Mn}, \mathrm{Cd}, \mathrm{Pb}, \mathrm{Ba}$, and $\mathrm{Cr}$ ) for both WW and TW. Table 1 shows the physical and chemical properties of the two water types used in this study. 
Table 1. Chemical and physical properties of the water types used for irrigation.

\begin{tabular}{ccc}
\hline Parameters & Well Water (WW) & Treated Wastewater (TW) \\
\hline $\mathrm{pH}$ & 7.15 & 7.82 \\
EC (Electrical Conductivity) $(\mu \mathrm{S} / \mathrm{cm})$ & 3560 & 2480 \\
TDS ppm (Total dissolved solids) & 1773 & 1253 \\
Total N (mg/L) & 5.8 & 9.2 \\
$\mathrm{P}$ & $2.2 \%$ & $1.7 \%$ \\
$\mathrm{~K}$ & $4.4 \%$ & $1.5 \%$ \\
$\mathrm{Ca}$ & $2.9 \%$ & $1.1 \%$ \\
$\mathrm{Mg}$ & $3.2 \%$ & $1.6 \%$ \\
$\mathrm{Na}$ & $1.1 \%$ & $1.8 \%$ \\
$\mathrm{~F}$ & $3.7 \%$ & $2.0 \%$ \\
$\mathrm{Cu}$ & $4.0 \%$ & $2.6 \%$ \\
$\mathrm{Zn}$ & $3.2 \%$ & $1.9 \%$ \\
$\mathrm{Mn}$ & $1.1 \%$ & $3.4 \%$ \\
$\mathrm{Cd}$ & $1.8 \%$ & $4.0 \%$ \\
$\mathrm{~Pb}$ & $2.1 \%$ & $1.8 \%$ \\
$\mathrm{Ba}$ & $2.2 \%$ & $1.5 \%$ \\
$\mathrm{Cr}$ & $2.4 \%$ & $1.6 \%$ \\
\hline
\end{tabular}

Soil samples were taken from each plot at the beginning and the end of the experiment at four different depths ranging from 0 to $70 \mathrm{~cm}$. All collected samples were pooled together according to type of water used for irrigation and were sent for analysis. Physical ( $\mathrm{pH}, \mathrm{EC}$, soil texture) and chemical $(\mathrm{P}, \mathrm{K}, \mathrm{Ca}, \mathrm{Mg}, \mathrm{Na}, \mathrm{Fe}, \mathrm{Cu}, \mathrm{Zn}, \mathrm{Mn}, \mathrm{Cd}, \mathrm{Pb}$ and $\mathrm{Cr}$ ) properties were examined, and samples were analyzed in the laboratories of KSU and the Ministry of Environment, Water and Agriculture in Saudi Arabia using Inductively Coupled Plasma-Mass Spectrometer (NexION 300D, Perkin Elmer, USA). Table 2 shows the physical and chemical properties of the soil samples at the beginning and end of the experiment.

Table 2. Chemical and physical properties of soils at the beginning and end of the experiment.

\begin{tabular}{cccc}
\hline \multirow{2}{*}{ Parameters (\%) } & Beginning of the Experiment & \multicolumn{2}{c}{ End of the Experiment } \\
\cline { 3 - 4 } & & WW & TW \\
\hline $\mathrm{pH}$ & 8.28 & 7.98 & 8.07 \\
$\mathrm{EC}$ & 0.25 & 0.49 & 0.22 \\
$\mathrm{Sand}$ & 62 & 60 & 54 \\
$\mathrm{Silt}$ & 28 & 30 & 34 \\
$\mathrm{Clay}$ & 10 & 10 & 12 \\
$\mathrm{P}$ & 8.2 & 4.1 & 4.8 \\
$\mathrm{~K}$ & 12.7 & 7.8 & 8.3 \\
$\mathrm{Ca}$ & 11.9 & 5.7 & 8 \\
$\mathrm{Mg}$ & $\mathrm{s}$ & 3.7 & 6.1 \\
$\mathrm{Na}$ & $\mathrm{s}^{*}$ & $\mathrm{~s}$ & $\mathrm{~s}$ \\
$\mathrm{Fe}$ & 11.3 & 6.5 & 7.7 \\
$\mathrm{Cu}$ & 11.7 & 7.1 & 4.8 \\
$\mathrm{Zn}$ & 83.8 & 2.7 & 8 \\
$\mathrm{Mn}$ & 7.6 & 6.8 & 2.7 \\
$\mathrm{Cd}$ & 53 & 18.3 & 25.8 \\
$\mathrm{~Pb}$ & 7 & 13.8 & 3.7 \\
$\mathrm{Cr}$ & 8.7 & 7.1 & 6 \\
\hline
\end{tabular}

${ }^{*} \mathrm{~s}$ indicates that reading was above upper sample concentration. 


\subsection{Plant Sampling and Analysis}

Each replicate of the four treatments (two cultivars $\times$ two water types) was harvested twice; first in the 2013/2014 season and second in the 2014/2015 season. Alfalfa plants were harvested at a height of $5 \mathrm{~cm}$ at the start of the flowering stage, and the collected aerial parts were immediately transferred to laboratories in the College of Food and Agriculture Science, KSU. The fresh green leaves were weighed, before being dried in an oven at $60{ }^{\circ} \mathrm{C}$ for $48 \mathrm{~h}$. Dried samples were weighed, and these weights were recorded. Dried samples were ground using a grinder (IKA ${ }^{\circledR}$, Staufen, Breisgau, Germany, MF 10.1 cutting-grinding head) with a speed range of $5500 \mathrm{rpm}$ and a grinding sieve with a diameter of $1 \mathrm{~mm}$.

Quantities of around $500 \mathrm{~g}$ of the powdered (dried and grinded) plant samples were packed in sealed plastic bags and shipped by air to Germany (Verband Deutscher Landwirtschaftlicher Untersuchungs- und Forschungsanstalten (VDLUFA) e. V. Germany and Landesbetrieb Hessisches Landeslabor, Germany) for nutrient contents analysis. Analysis of nutrient contents was performed using a near-infrared spectroscopy (NIRS) instrument (Technicon 500, Technicon Industrial Systems, NY, USA).

\subsection{Statistical Analysis}

Data were analyzed using Analysis of Variance (ANOVA) on IBM SPSS Statistics 20 with three factors, cultivar, cutting time, and water type. Means are reported as averages of three replicates and were separated by Duncan's Multiple Range Test $(P \leq 0.05)$. Correlation analyses between nutrient contents in alfalfa samples were performed using Pearson's correlation analysis on IBM SPSS Statistics 20 .

\section{Results and Discussion}

In the current study, the effect of using TW on the metal contents of two alfalfa cultivars was examined. Concentrations of macronutrients $(\mathrm{N}, \mathrm{P}, \mathrm{K}, \mathrm{Ca}, \mathrm{Mg}$, and $\mathrm{S})$ and micronutrients $(\mathrm{Na}, \mathrm{Cl}, \mathrm{Cu}$, $\mathrm{Zn}, \mathrm{Fe}, \mathrm{Mn}, \mathrm{Pb}, \mathrm{Ni}$, and $\mathrm{Co}$ ) were also estimated. The obtained results showed that all of the studied independent variables (water type, cultivar, and cutting time) had a significant $(P \leq 0.05)$ effect on macronutrient and micronutrient contents in alfalfa plants. Furthermore, the interactions between each pair of independent variables, and the overall interactions between the studied parameters, produced significant $(P \leq 0.05)$ differences in nutrient contents in the plants. Although $\mathrm{K}$ and Ca contents were higher in WW as compared to TW (Table 1), irrigation with TW produced plants with slightly higher $\mathrm{K}$ and Ca contents, while no differences in S content were observed between plants irrigated with WW and plants irrigated with TW. This agrees with the results obtained by Chávez, et al. [11], who found that irrigation with untreated wastewater led to higher $S$ levels in alfalfa tissues than that with partially TW. Enhancement of nutrient uptake was reported as one of beneficial gains of irrigation with TW $[29,30]$. Nevertheless, plants irrigated with TW had lower N, P, and Mg contents than those irrigated with WW, regardless of cutting time and cultivar (Table 3). Furthermore, irrigation with TW led to slight decreases in the contents of all studied micronutrients apart from $\mathrm{Cl}$, which increased by an average of $3.2 \%$ compared to plants irrigated with WW. Surprisingly, the contents of Mn and Cd in plants irrigated with TW were lower than in those irrigated with WW; however, TW was characterized by higher Mn and Cd contents as compared to WW. Hussain et al. [31] showed that levels of different heavy metals (i.e., $\mathrm{Cd}, \mathrm{Co}, \mathrm{Cu}, \mathrm{Mn}, \mathrm{Zn}, \mathrm{Pb}, \mathrm{Ni}$ and $\mathrm{Cr}$ ) in radish, spinach and carrot plants irrigated with TW were below toxic limits, but plants irrigated with 100\% TW had lower contents of heavy metals as compared to others irrigated with $25 \%, 50 \%$ and $75 \%$ TW. In general, metals uptake could be affected by several factors including plant cultivar (genotype), external concentrations, and soil $\mathrm{pH}$. Although soils irrigated with TW showed a roughly $50 \%$ decrease in Pb content (Table 2), no differences in $\mathrm{Pb}$ content were observed between treatments (Table 4). Such a result could be partially explained by the ability of $\mathrm{Pb}$ to move in the soil solution and leach to the underground water [32], in addition to its high dependability on the solubility and pH of soil [33]. Chávez, et al. [11] studied 
alfalfa tissues and found that $\mathrm{Cu}$ and $\mathrm{Zn}$ were the most sensitive micronutrients to irrigation with wastewater; however, in the present study, significant decreases in N, P, and K contents were observed after irrigation with TW. Variations were also detected in the macronutrient and micronutrient contents of the different cultivars, regardless of cutting time and the type of water used for irrigation. Plants of the Alhassawy cultivar contained higher $\mathrm{N}, \mathrm{P}$, and $\mathrm{K}$ contents but lower $\mathrm{Ca}, \mathrm{Mg}$, and $\mathrm{S}$ contents than plants of the CUV101 cultivar (Table 3). In general, cultivar variation affects several alfalfa yield traits, including morphology, forage quality, overall yield [34], and elemental composition of the plant shoots [35]. It is perhaps unsurprising, then, that plants of the Alhassawy cultivar had higher contents of all micronutrients apart from $\mathrm{Cu}, \mathrm{Zn}$, and Co than plants of the CUV101 cultivar (Table 4). James et al. [36] examined five different cultivars of alfalfa and found significant variations in P, Ca, $\mathrm{Na}, \mathrm{Mn}, \mathrm{Sr}$, and Zn contents. The plant material obtained in the first cutting period (2013/2014) had higher contents of the majority of macronutrients and micronutrients than plant materials obtained during the second cutting period (2014/2015). This could be correlated with the reduction observed in contents of macronutrients in the soils irrigated with TW or WW at the end of the experiment. It was previously reported that long-term application of TW led to significant reductions in plants' contents of heavy metals [37]. Another study that sampled alfalfa cultivated lands that had been irrigated with TW since 80 years found that levels of $\mathrm{Fe}, \mathrm{Cu}, \mathrm{Zn}$ and $\mathrm{Mn}$ were higher if compared with their levels in soils irrigated with potable water [38]. The exceptions to this were $\mathrm{S}, \mathrm{Na}, \mathrm{Ni}$, and $\mathrm{Co}$, which were present in higher contents in plants obtained during the second cutting period than the first cutting period (Tables 3 and 4). Other studies have also shown that cutting time significantly affects the yield, nutritive value, and elemental composition of alfalfa plants [39].

Table 3. Effects of cutting time, cultivar, and water type used for irrigation on alfalfa macronutrient contents.

\begin{tabular}{cccccccc}
\hline \multicolumn{2}{c}{ Factor } & N (\%) & P (\%) & K (\%) & Ca (\%) & Mg (\%) & S (\%) \\
\hline \multirow{2}{*}{ Cutting time } & 1 & $3.60 \mathrm{a}$ & $0.26 \mathrm{a}$ & $2.87 \mathrm{a}$ & $3.27 \mathrm{a}$ & $0.38 \mathrm{a}$ & $0.37 \mathrm{~b}$ \\
& 2 & $2.96 \mathrm{~b}$ & $0.21 \mathrm{~b}$ & $2.24 \mathrm{~b}$ & $1.82 \mathrm{~b}$ & $0.31 \mathrm{~b}$ & $0.39 \mathrm{a}$ \\
\hline \multicolumn{2}{c}{ LSD $(P \leq 0.05)$} & 0.02 & 0.01 & 0.01 & 0.02 & 0.01 & 0.01 \\
\hline \multirow{2}{*}{ Cultivar } & Alhassawy & $3.12 \mathrm{~b}$ & $0.21 \mathrm{~b}$ & $2.07 \mathrm{~b}$ & $3.07 \mathrm{a}$ & $0.35 \mathrm{a}$ & $0.38 \mathrm{a}$ \\
& CUV101 & $3.44 \mathrm{a}$ & $0.26 \mathrm{a}$ & $3.04 \mathrm{a}$ & $2.02 \mathrm{~b}$ & $0.34 \mathrm{~b}$ & $0.37 \mathrm{a}$ \\
\hline \multicolumn{2}{c}{ LSD $(P \leq 0.05)$} & 0.02 & 0.01 & 0.01 & 0.021 & 0.01 & 0.01 \\
\hline \multirow{2}{*}{ Water type } & WW & $3.30 \mathrm{a}$ & $0.24 \mathrm{a}$ & $2.51 \mathrm{~b}$ & $2.42 \mathrm{~b}$ & $0.35 \mathrm{a}$ & $0.38 \mathrm{a}$ \\
& TW & $3.25 \mathrm{~b}$ & $0.23 \mathrm{~b}$ & $2.60 \mathrm{a}$ & $2.68 \mathrm{a}$ & $0.33 \mathrm{~b}$ & $0.38 \mathrm{a}$ \\
\hline \multicolumn{2}{c}{ LSD $(P \leq 0.05)$} & 0.02 & 0.01 & 0.01 & 0.02 & 0.01 & 0.01 \\
\hline
\end{tabular}

Means followed by the same letter are not significantly different $(P \leq 0.05)$. LSD: Least Significant Difference.

Table 4. Effects of cutting time, cultivar, and water type used for irrigation on alfalfa micronutrient contents.

\begin{tabular}{|c|c|c|c|c|c|c|c|c|c|c|}
\hline \multirow{2}{*}{\multicolumn{2}{|c|}{ Factor }} & \multirow{2}{*}{$\mathrm{Na}(\%)$} & \multirow{2}{*}{$\mathrm{Cl}(\%)$} & $\mathrm{Cu}$ & $\mathrm{Zn}$ & $\mathrm{Fe}$ & Mn & $\mathrm{Pb}$ & $\mathrm{Ni}$ & Co \\
\hline & & & & \multicolumn{7}{|c|}{ (mg/kg) } \\
\hline \multirow{2}{*}{ Cutting time } & 1 & $0.17 \mathrm{~b}$ & $1.41 \mathrm{a}$ & $7.80 \mathrm{a}$ & $32.37 \mathrm{a}$ & $312.75 \mathrm{a}$ & $41.79 \mathrm{a}$ & $0.51 \mathrm{a}$ & $1.19 \mathrm{~b}$ & $0.16 \mathrm{~b}$ \\
\hline & 2 & $0.32 \mathrm{a}$ & $1.13 \mathrm{~b}$ & $6.48 \mathrm{~b}$ & $21.20 \mathrm{~b}$ & $185.17 \mathrm{~b}$ & $40.15 \mathrm{~b}$ & $0.50 \mathrm{a}$ & $1.70 \mathrm{a}$ & $0.17 \mathrm{a}$ \\
\hline \multicolumn{2}{|c|}{$\operatorname{LSD}(P \leq 0.05)$} & 0.01 & 0.03 & 0.16 & 0.35 & 2.18 & 0.53 & 0.01 & 0.01 & 0.01 \\
\hline \multirow{2}{*}{ Cultivar } & Alhassawy & $0.33 a$ & $1.37 \mathrm{a}$ & $6.13 \mathrm{~b}$ & $25.40 \mathrm{~b}$ & $282.08 \mathrm{a}$ & $41.91 \mathrm{a}$ & $0.51 \mathrm{a}$ & $1.31 \mathrm{a}$ & $0.16 \mathrm{~b}$ \\
\hline & CUV101 & $0.16 \mathrm{~b}$ & $1.17 \mathrm{~b}$ & $8.15 \mathrm{a}$ & $28.17 \mathrm{a}$ & $218.83 \mathrm{~b}$ & $40.03 \mathrm{~b}$ & $0.50 \mathrm{a}$ & $1.57 \mathrm{~b}$ & $0.18 \mathrm{a}$ \\
\hline \multicolumn{2}{|c|}{$\operatorname{LSD}(P \leq 0.05)$} & 0.01 & 0.03 & 0.16 & 0.35 & 2.18 & 0.53 & 0.01 & 0.01 & 0.01 \\
\hline \multirow{2}{*}{ Water type } & WW & $0.28 \mathrm{a}$ & $1.25 \mathrm{~b}$ & $8.03 \mathrm{a}$ & $27.28 \mathrm{a}$ & $275.00 \mathrm{a}$ & $41.78 \mathrm{a}$ & $0.51 \mathrm{a}$ & $1.58 \mathrm{a}$ & $0.19 \mathrm{a}$ \\
\hline & TW & $0.21 \mathrm{~b}$ & $1.29 \mathrm{a}$ & $6.25 \mathrm{~b}$ & $26.28 \mathrm{~b}$ & $222.92 \mathrm{~b}$ & $40.47 \mathrm{~b}$ & $0.51 \mathrm{a}$ & $1.30 \mathrm{~b}$ & $0.15 \mathrm{~b}$ \\
\hline \multicolumn{2}{|c|}{$\operatorname{LSD}(P \leq 0.05)$} & 0.01 & 0.03 & 0.16 & 0.35 & 2.18 & 0.53 & 0.01 & 0.01 & 0.01 \\
\hline
\end{tabular}

Means followed by the same letter are not significantly different $(P \leq 0.05)$. LSD: Least Significant Difference. 
The interaction between each pair of independent variables significantly $(P \leq 0.05)$ affected the nutrient content of alfalfa plants. Tables 5 and 6 show the interactive effects between each pair of independent variables on alfalfa macronutrient and micronutrient contents, respectively. Alhassawy cultivar plants irrigated with WW showed the highest contents of all macronutrients (apart from S, as no significant differences in $\mathrm{S}$ content were observed in any of the studied plants), and most micronutrients (except $\mathrm{Na}$ and $\mathrm{Ni}$ ) compared to Alhassawy plants irrigated with TW, CUV101 plants irrigated with TW, and CUV101 plants irrigated with WW. CUV101 plants irrigated with WW contained the highest $\mathrm{Na}$ and $\mathrm{Ni}$ contents out of any of the treatments. The interaction between cutting time and water type used for irrigation did not produce significant variations in micronutrient contents among the different treatments; however, plants obtained in the second cutting period had lower nutrient contents than those obtained in the first cutting period. Plants from the first cutting period irrigated with WW contained the highest micronutrient contents apart from $\mathrm{Na}$ and $\mathrm{Ni}$, which were highest in plants from the second cutting period irrigated with $\mathrm{WW}$. There was no significant variation in $\mathrm{Pb}$ content among any of the treatments. CUV101 plants obtained in the first cutting period had the highest contents of all macronutrients except $\mathrm{S}$ and $\mathrm{Ca}$, which were highest in CUV101 plants of the second cutting period and in Alhassawy plants obtained during the first cutting period, respectively. The contents of several micronutrients $(\mathrm{Cl}, \mathrm{Fe}, \mathrm{Mn}$, and $\mathrm{Co}$ ) were highest in Alhassawy plants from the first cutting period. However, the contents of other micronutrients $(\mathrm{Cu}, \mathrm{Zn})$ were higher in CUV101 plants of the first cutting period. No significant changes in $\mathrm{Pb}$ content were observed among the treatments, and the highest Co content was found in CUV101 plants obtained during the second period. The results obtained in this study indicate that the effect of irrigation water quality significantly depends on other factors, mainly cultivar and cutting time. For example, irrigation with saline water has been shown to affect total forage production and iron relations (including iron uptake and translocation inside the plant tissues) in alfalfa plants, and this effect varies from one cultivar to another [40]. Nevertheless, usage of untreated wastewater increases yield as well as $\mathrm{N}, \mathrm{P}, \mathrm{K}, \mathrm{Ca}, \mathrm{Mg}, \mathrm{Na}, \mathrm{Fe}, \mathrm{Mn}, \mathrm{Zn}, \mathrm{Cu}, \mathrm{Pb}, \mathrm{Ni}$, and Cd contents in cauliflower (Brassica oleracea $\mathrm{L}$. var. botrytis) and red cabbage (Brassica oleracea $\mathrm{L}$. var. rubra), without contaminating the soil or plant tissues with heavy metals [41].

Table 5. Effects of the interactions between each pair of independent variables on alfalfa macronutrient contents.

\begin{tabular}{|c|c|c|c|c|c|c|c|}
\hline \multicolumn{2}{|c|}{ Interacting Variables } & $\mathbf{N}(\%)$ & $\mathbf{P}(\%)$ & K (\%) & $\mathrm{Ca}(\%)$ & $\operatorname{Mg}(\%)$ & $\mathrm{S}(\%)$ \\
\hline \multirow{4}{*}{$\begin{array}{l}\text { Cutting time } \times \\
\text { cultivar }\end{array}$} & $1 \times$ Alhassawy & $3.46 \mathrm{~b}$ & $0.23 \mathrm{~b}$ & $2.28 \mathrm{c}$ & $4.05 \mathrm{a}$ & $0.38 \mathrm{a}$ & $0.35 c$ \\
\hline & $1 \times$ CUV101 & $3.74 \mathrm{a}$ & $0.29 \mathrm{a}$ & $3.45 \mathrm{a}$ & $2.49 \mathrm{~b}$ & $0.37 \mathrm{a}$ & $0.39 \mathrm{~b}$ \\
\hline & $2 \times$ Alhassawy & $2.78 \mathrm{~d}$ & $0.20 \mathrm{c}$ & $1.85 \mathrm{~d}$ & $2.09 \mathrm{c}$ & $0.31 \mathrm{~b}$ & $0.42 \mathrm{a}$ \\
\hline & $2 \times$ CUV101 & $3.14 \mathrm{a}$ & $0.23 \mathrm{~b}$ & $2.63 \mathrm{~b}$ & $1.55 \mathrm{~d}$ & $0.31 \mathrm{~b}$ & $0.36 \mathrm{bc}$ \\
\hline \multicolumn{2}{|c|}{$\operatorname{LSD}(P \leq 0.05)$} & 0.11 & 0.02 & 0.14 & 0.29 & 0.02 & 0.03 \\
\hline \multirow{4}{*}{$\begin{array}{l}\text { Cutting time } \times \\
\text { water type }\end{array}$} & $1 \times W W$ & $3.68 \mathrm{a}$ & $0.27 \mathrm{a}$ & $2.91 \mathrm{a}$ & $3.10 \mathrm{a}$ & $0.40 \mathrm{a}$ & $0.38 \mathrm{a}$ \\
\hline & $1 \times \mathrm{TW}$ & $3.52 \mathrm{a}$ & $0.25 \mathrm{ab}$ & $2.83 \mathrm{a}$ & $3.44 \mathrm{a}$ & $0.36 \mathrm{~b}$ & $0.36 \mathrm{a}$ \\
\hline & $2 \times W W$ & $2.93 \mathrm{~b}$ & $0.21 \mathrm{~b}$ & $2.11 \mathrm{~b}$ & $1.72 \mathrm{~b}$ & $0.30 \mathrm{c}$ & $0.38 \mathrm{a}$ \\
\hline & $2 \times \mathrm{TW}$ & $2.98 \mathrm{~b}$ & $0.22 \mathrm{~b}$ & $2.37 \mathrm{ab}$ & $1.91 \mathrm{~b}$ & $0.31 \mathrm{c}$ & $0.40 \mathrm{a}$ \\
\hline \multicolumn{2}{|c|}{$\operatorname{LSD}(P \leq 0.05)$} & 0.23 & 0.04 & 0.66 & 0.80 & 0.02 & 0.05 \\
\hline \multirow{4}{*}{$\begin{array}{l}\text { Cultivar } \times \text { water } \\
\text { type }\end{array}$} & Alhassawy $\times$ WW & $3.68 \mathrm{a}$ & $0.27 \mathrm{a}$ & $2.91 \mathrm{a}$ & $3.10 \mathrm{a}$ & $0.40 \mathrm{a}$ & $0.38 \mathrm{a}$ \\
\hline & Alhassawy $\times$ TW & $3.52 \mathrm{a}$ & $0.25 \mathrm{ab}$ & $2.83 \mathrm{a}$ & $3.44 \mathrm{a}$ & $0.36 \mathrm{~b}$ & $0.36 \mathrm{a}$ \\
\hline & CUV101 × WW & $2.93 \mathrm{~b}$ & $0.21 \mathrm{~b}$ & $2.11 \mathrm{~b}$ & $1.72 \mathrm{~b}$ & $0.30 \mathrm{c}$ & $0.38 \mathrm{a}$ \\
\hline & CUV101× TW & $2.98 \mathrm{~b}$ & $0.22 \mathrm{~b}$ & $2.37 \mathrm{ab}$ & $1.91 \mathrm{~b}$ & $0.31 \mathrm{c}$ & $0.40 \mathrm{a}$ \\
\hline \multicolumn{2}{|c|}{$\operatorname{LSD}(P \leq 0.05)$} & 0.23 & 0.04 & 0.66 & 0.80 & 0.02 & 0.05 \\
\hline
\end{tabular}

Means followed by the same letter are not significantly different $(P \leq 0.05)$. LSD: Least Significant Difference. 
Table 6. Effects of the interactions between each pair of independent variables on alfalfa macronutrient contents.

\begin{tabular}{|c|c|c|c|c|c|c|c|c|c|c|}
\hline \multirow{2}{*}{\multicolumn{2}{|c|}{ Interacting Variables }} & \multirow[t]{2}{*}{$\mathrm{Na}(\%)$} & \multirow{2}{*}{$\mathrm{Cl}(\%)$} & $\mathrm{Cu}$ & Zn & $\mathrm{Fe}$ & Mn & $\mathrm{Pb}$ & $\mathrm{Ni}$ & Co \\
\hline & & & & \multicolumn{7}{|c|}{$(\mathrm{mg} / \mathrm{kg})$} \\
\hline \multirow{4}{*}{$\begin{array}{l}\text { Cutting } \\
\text { time } \times \\
\text { cultivar }\end{array}$} & $1 \times$ Alhassawy & $0.20 \mathrm{~b}$ & $1.49 \mathrm{a}$ & $5.88 \mathrm{~b}$ & $28.63 \mathrm{~b}$ & $359.50 \mathrm{a}$ & $43.58 \mathrm{a}$ & $0.52 \mathrm{a}$ & $1.23 \mathrm{~b}$ & $0.18 \mathrm{ab}$ \\
\hline & $1 \times$ CUV101 & $0.14 \mathrm{~b}$ & $1.33 \mathrm{~b}$ & $9.72 \mathrm{a}$ & $36.10 \mathrm{a}$ & $266.00 \mathrm{~b}$ & $40.00 \mathrm{~b}$ & $0.51 \mathrm{a}$ & $1.16 \mathrm{~b}$ & $0.15 \mathrm{~b}$ \\
\hline & $2 \times$ Alhassawy & $0.47 \mathrm{a}$ & $1.25 \mathrm{~b}$ & $6.38 \mathrm{~b}$ & $22.17 \mathrm{c}$ & $204.67 \mathrm{c}$ & $40.23 b$ & $0.51 \mathrm{a}$ & $1.40 \mathrm{~b}$ & $0.15 \mathrm{~b}$ \\
\hline & $2 \times$ CUV101 & $0.18 \mathrm{~b}$ & $1.01 \mathrm{c}$ & $6.58 \mathrm{~b}$ & $20.24 \mathrm{c}$ & $165.67 \mathrm{c}$ & $40.06 \mathrm{~b}$ & $0.50 \mathrm{a}$ & $1.99 \mathrm{a}$ & $0.20 \mathrm{a}$ \\
\hline \multicolumn{2}{|c|}{$\operatorname{LSD}(P \leq 0.05)$} & 0.07 & 0.11 & 1.79 & 3.30 & 40.27 & 2.00 & 0.02 & 0.24 & 0.03 \\
\hline Cutting & $1 \times W W$ & $0.19 \mathrm{~b}$ & $1.45 \mathrm{a}$ & $9.85 \mathrm{a}$ & $35.27 \mathrm{a}$ & 353.17 a & $43.03 \mathrm{a}$ & $0.52 \mathrm{a}$ & $1.23 \mathrm{~b}$ & $0.19 \mathrm{ab}$ \\
\hline time $\times$ & $1 \times \mathrm{TW}$ & $0.15 \mathrm{~b}$ & $1.36 \mathrm{a}$ & $6.02 \mathrm{~b}$ & $29.47 \mathrm{~b}$ & $272.33 \mathrm{~b}$ & $40.55 \mathrm{~b}$ & $0.51 \mathrm{a}$ & $1.15 \mathrm{~b}$ & $0.14 \mathrm{c}$ \\
\hline water & $2 \times W W$ & $0.37 \mathrm{a}$ & $1.05 \mathrm{c}$ & $6.48 \mathrm{~b}$ & $19.30 \mathrm{~d}$ & $196.83 \mathrm{c}$ & $39.92 b$ & $0.51 \mathrm{a}$ & $1.93 \mathrm{a}$ & $0.20 \mathrm{a}$ \\
\hline type & $2 \times \mathrm{TW}$ & $0.28 \mathrm{ab}$ & $1.21 \mathrm{~b}$ & $6.48 \mathrm{~b}$ & $23.10 \mathrm{c}$ & $173.50 \mathrm{c}$ & $40.38 \mathrm{~b}$ & $0.50 \mathrm{a}$ & $1.45 \mathrm{~b}$ & $0.16 \mathrm{bc}$ \\
\hline \multicolumn{2}{|c|}{$\operatorname{LSD}(P \leq 0.05)$} & 0.15 & 0.15 & 1.91 & 3.64 & 48.11 & 2.32 & 0.02 & 0.29 & 0.03 \\
\hline Cultivar & Alhassawy $\times$ WW & $0.19 \mathrm{~b}$ & $1.45 \mathrm{a}$ & $9.85 \mathrm{a}$ & $35.27 \mathrm{a}$ & $353.17 \mathrm{a}$ & $43.03 \mathrm{a}$ & $0.52 \mathrm{a}$ & $1.23 \mathrm{~b}$ & $0.19 \mathrm{ab}$ \\
\hline$x$ & Alhassawy $\times \mathrm{TW}$ & $0.15 \mathrm{~b}$ & $1.36 \mathrm{a}$ & $6.02 \mathrm{~b}$ & $29.47 \mathrm{~b}$ & $272.33 \mathrm{~b}$ & $40.55 \mathrm{~b}$ & $0.51 \mathrm{a}$ & $1.15 \mathrm{~b}$ & $0.14 \mathrm{c}$ \\
\hline water & CUV101 ×WW & $0.37 \mathrm{a}$ & $1.05 \mathrm{c}$ & $6.48 \mathrm{~b}$ & $19.30 \mathrm{~d}$ & $196.83 \mathrm{c}$ & $39.92 b$ & $0.51 \mathrm{a}$ & $1.93 \mathrm{a}$ & $0.20 \mathrm{a}$ \\
\hline type & CUV101 × TW & $0.28 \mathrm{ab}$ & $1.21 \mathrm{~b}$ & $6.48 \mathrm{~b}$ & $23.10 \mathrm{c}$ & $173.50 \mathrm{c}$ & $40.38 \mathrm{~b}$ & $0.50 \mathrm{a}$ & $1.45 \mathrm{~b}$ & $0.16 b c$ \\
\hline \multicolumn{2}{|c|}{$\operatorname{LSD}(P \leq 0.05)$} & 0.15 & 0.15 & 1.91 & 3.64 & 48.11 & 2.32 & 0.02 & 0.29 & 0.03 \\
\hline
\end{tabular}

Means followed by the same letter are not significantly different $(P \leq 0.05)$. LSD: Least Significant Difference.

The results obtained in the current study demonstrate that the overall interaction between the studied variables, namely, water type used for irrigation, cultivar, and cutting time, significantly $(P \leq 0.05)$ affected alfalfa macronutrient and micronutrient contents. CUV101 plants obtained in the first cutting period that were irrigated with $\mathrm{WW}$ showed the highest $\mathrm{N}, \mathrm{P}$, and $\mathrm{Mg}$ contents. There were no differences in P content for first cutting period CUV101 plants irrigated with TW (Table 7). Furthermore, first cutting period CUV101 plants irrigated with TW contained the highest K content among all the studied treatments. Moreover, Alhassawy plants irrigated with TW obtained in the first and the second cutting periods showed the highest $\mathrm{Ca}$ and $\mathrm{S}$ contents, respectively. $\mathrm{N}, \mathrm{K}, \mathrm{Mg}$, and $\mathrm{Na}$ contents in alfalfa plants irrigated with TW were higher than in plants irrigated with tap water [42]. Regarding the present study, the effects of the three independent variables on alfalfa micronutrient contents are shown in Table 8. Alhassawy plants obtained in the first cutting period that were irrigated with $\mathrm{WW}$ had the highest $\mathrm{Fe}, \mathrm{Mn}$, and $\mathrm{Pb}$ contents. In contrast, $\mathrm{Al}-\mathrm{Karaki}$ [42] found that $\mathrm{Pb}$ and $\mathrm{Ni}$ contents were higher in plants irrigated with TW than in plants irrigated with tap water. Irrigation with TW did not increase $\mathrm{Cl}$ content in the tissues of Alhassawy plants obtained in the first cutting period. The highest $\mathrm{Cu}$ and $\mathrm{Zn}$ contents were found in tissues of CUV101 plants irrigated with WW and harvested in the first cutting period. Higher $\mathrm{Zn}$ content in alfalfa tissues is considered an undesirable trait because it can lead to problems in crop yield. This is mainly due to the antagonistic effect of $\mathrm{Zn}$ against $\mathrm{N}$ in different parts of the plant [43], which might lead to $\mathrm{N}$ deficiency and, consequently, affect yield. In contrast, our results showed a significantly strong positive association between Zn content and $\mathrm{N}$ content (Table 9). The highest $\mathrm{Ni}$ and Co contents were found in Alhassawy plants irrigated with WW that were harvested in the second cutting period. The highest Na content was observed in Alhassawy plants irrigated with WW that were harvested in the second cutting period. The crucial nutrients for the health of alfalfa plants are $\mathrm{N}, \mathrm{P}, \mathrm{K}, \mathrm{Ca}, \mathrm{Mg}$, and $\mathrm{Na}$ [44]. Our results demonstrate that irrigation with TW does not lead to dramatic decreases in the contents of these nutrients within plants. Nevertheless, irrigation with TW does lead to significant increases in K and Ca contents, without any adverse effects on P content. These results agree with those found in a study by Chávez et al. [11], who studied alfalfa irrigated with untreated or partially TW. Kiziloglu et al. [41] concluded that untreated wastewater can be used confidently, on a short-term basis, in agricultural land, while primary TW is suitable for long-term use in sustainable agriculture. Irrigation with TW has been shown to greatly enhance the physiological status, enzymatic activity, and nutritional composition of alfalfa plants, compared to irrigation with WW [45]. Changes in the contents of macro and micronutrients in plants 
irrigated with TW could be attributed to several factors including the accumulation of heavy metals inside the plant tissues, which hamper the uptake of other essential ions. In the current study, a negative correlation between $\mathrm{Ni}$ and $\mathrm{Mg}$ contents was observed, evidence for the effect of heavy metals leading to decreased uptake of essential nutrients. Another factor is the presence of contaminants (e.g., pharmaceutical) that might stimulate or hinder the uptake of specific nutrients [46]. Such contaminants might bind to a plant cell's membrane fraction and thus facilitate or obscure the flux of several ions, e.g., $\mathrm{Ca}^{2+}[47,48]$. Moreover, some nutrients play critical roles in a plant's tolerance to heavy metals, which might explain the vast increase in their levels in plant tissues. In the current study, increased levels of certain heavy metals (i.e., $\mathrm{Fe}, \mathrm{CU}, \mathrm{Zn}$ and $\mathrm{Mn}$ ) were associated with an increase in magnesium levels. $\mathrm{Mg}$ was shown to have a potential role in heavy metal stress tolerance in mangrove [49] and soybean [50] plants.

Table 7. Effect of the overall interaction between cutting time, cultivar, and water type on alfalfa macronutrient contents.

\begin{tabular}{ccccccccc}
\hline Cutting Time & Cultivar & Water Type & N (\%) & $\mathbf{P ~ ( \% ) ~}$ & K (\%) & Ca (\%) & Mg (\%) & S (\%) \\
\hline 1 & Alhassawy & WW & $3.54 \mathrm{c}$ & $0.24 \mathrm{~b}$ & $2.38 \mathrm{e}$ & $3.76 \mathrm{~b}$ & $0.40 \mathrm{a}$ & $0.37 \mathrm{bc}$ \\
1 & Alhassawy & TW & $3.39 \mathrm{~d}$ & $0.21 \mathrm{c}$ & $2.18 \mathrm{f}$ & $4.35 \mathrm{a}$ & $0.36 \mathrm{~b}$ & $0.32 \mathrm{~d}$ \\
1 & CUV101 & WW & $3.82 \mathrm{a}$ & $0.30 \mathrm{a}$ & $3.43 \mathrm{~b}$ & $2.45 \mathrm{~d}$ & $0.39 \mathrm{a}$ & $0.38 \mathrm{~b}$ \\
1 & CUV101 & TW & $3.65 \mathrm{~b}$ & $0.28 \mathrm{a}$ & $3.48 \mathrm{a}$ & $2.54 \mathrm{c}$ & $0.35 \mathrm{~b}$ & $0.39 \mathrm{~b}$ \\
2 & Alhassawy & WW & $2.83 \mathrm{~g}$ & $0.18 \mathrm{~d}$ & $1.73 \mathrm{~h}$ & $1.79 \mathrm{f}$ & $0.31 \mathrm{c}$ & $0.39 \mathrm{~b}$ \\
2 & Alhassawy & TW & $2.72 \mathrm{~h}$ & $0.21 \mathrm{c}$ & $1.97 \mathrm{~g}$ & $2.38 \mathrm{e}$ & $0.31 \mathrm{c}$ & $0.45 \mathrm{a}$ \\
2 & CUV101 & WW & $3.03 \mathrm{f}$ & $0.24 \mathrm{~b}$ & $2.49 \mathrm{~d}$ & $1.65 \mathrm{~g}$ & $0.30 \mathrm{c}$ & $0.38 \mathrm{~b}$ \\
2 & CUV101 & TW & $3.25 \mathrm{~d}$ & $0.22 \mathrm{c}$ & $2.77 \mathrm{c}$ & $1.44 \mathrm{~h}$ & $0.31 \mathrm{c}$ & $0.35 \mathrm{c}$ \\
\hline
\end{tabular}

Means followed by the same letter are not significantly different $(P \leq 0.05)$. LSD: Least Significant Difference. 
Table 8. Effect of the overall interaction between cutting time, cultivar, and water type on alfalfa micronutrient contents.

\begin{tabular}{|c|c|c|c|c|c|c|c|c|c|c|c|}
\hline $\begin{array}{l}\text { Cutting } \\
\text { Time }\end{array}$ & Cultivar & $\begin{array}{l}\text { Water } \\
\text { Type }\end{array}$ & $\mathrm{Na}(\%)$ & $\mathrm{Cl}(\%)$ & $\begin{array}{c}\mathrm{Cu} \\
(\mathrm{mg} / \mathrm{kg})\end{array}$ & $\mathrm{Zn}$ (mg/kg) & $\mathrm{Fe}(\mathrm{mg} / \mathrm{kg})$ & $\begin{array}{c}\mathrm{Mn} \\
(\mathrm{mg} / \mathrm{kg})\end{array}$ & $\mathrm{Pb}(\mathrm{mg} / \mathrm{kg})$ & $\mathrm{Ni}(\mathrm{mg} / \mathrm{kg})$ & $\mathrm{Co}(\mathrm{mg} / \mathrm{kg})$ \\
\hline 1 & Alhassawy & WW & $0.22 \mathrm{c}$ & $1.50 \mathrm{a}$ & $7.40 \mathrm{bc}$ & $31.57 \mathrm{c}$ & $409.00 \mathrm{a}$ & $46.40 \mathrm{a}$ & $0.53 \mathrm{a}$ & $1.28 \mathrm{~d}$ & $0.21 \mathrm{~b}$ \\
\hline 1 & Alhassawy & TW & $0.19 \mathrm{~d}$ & $1.47 \mathrm{a}$ & $4.37 \mathrm{f}$ & $25.70 \mathrm{~d}$ & $310.00 \mathrm{~b}$ & $40.77 \mathrm{~b}$ & $0.50 \mathrm{~b}$ & $1.17 \mathrm{e}$ & 0.15 de \\
\hline 1 & CUV101 & WW & $0.17 \mathrm{~d}$ & $1.40 \mathrm{~b}$ & 11.77 a & $38.97 \mathrm{a}$ & 297.33 c & $39.67 \mathrm{~b}$ & $0.50 \mathrm{~b}$ & $1.18 \mathrm{e}$ & $0.16 \mathrm{~cd}$ \\
\hline 1 & CUV101 & TW & $0.11 \mathrm{e}$ & $1.25 \mathrm{c}$ & $7.67 \mathrm{~b}$ & $33.23 \mathrm{~b}$ & $234.67 \mathrm{~d}$ & $40.33 \mathrm{~b}$ & $0.51 \mathrm{~b}$ & $1.13 \mathrm{f}$ & $0.14 \mathrm{e}$ \\
\hline 2 & Alhassawy & WW & $0.57 \mathrm{a}$ & $1.13 \mathrm{~d}$ & $7.00 \mathrm{~d}$ & $20.60 \mathrm{~g}$ & $214.67 \mathrm{e}$ & $40.00 \mathrm{~b}$ & $0.50 \mathrm{~b}$ & $1.73 \mathrm{c}$ & $0.16 \mathrm{~cd}$ \\
\hline 2 & Alhassawy & TW & $0.36 \mathrm{~b}$ & $1.37 \mathrm{~b}$ & $5.77 \mathrm{e}$ & $23.73 \mathrm{e}$ & $194.67 \mathrm{f}$ & $40.47 \mathrm{~b}$ & $0.51 \mathrm{~b}$ & $1.06 \mathrm{~g}$ & $0.14 \mathrm{e}$ \\
\hline 2 & CUV101 & WW & $0.17 \mathrm{~d}$ & $0.97 \mathrm{f}$ & $5.97 \mathrm{e}$ & $18.00 \mathrm{~h}$ & $179.00 \mathrm{~g}$ & $39.83 \mathrm{~b}$ & $0.50 \mathrm{~b}$ & $2.13 \mathrm{a}$ & $0.23 \mathrm{a}$ \\
\hline 2 & CUV101 & TW & $0.19 \mathrm{~d}$ & $1.05 \mathrm{e}$ & $7.20 \mathrm{~cd}$ & $22.47 \mathrm{f}$ & $152.33 \mathrm{~h}$ & $40.29 \mathrm{~b}$ & $0.50 \mathrm{~b}$ & $1.84 \mathrm{~b}$ & $0.17 \mathrm{c}$ \\
\hline \multicolumn{3}{|c|}{$\operatorname{LSD}(P \leq 0.05)$} & 0.02 & 0.07 & 0.31 & 0.70 & 4.36 & 1.07 & 0.02 & 0.02 & 0.01 \\
\hline
\end{tabular}

Means followed by the same letter are not significantly different $(P \leq 0.05)$. LSD: Least Significant Difference.

Table 9. Pearson's correlation coefficients between the contents of different nutrients in alfalfa plants.

\begin{tabular}{|c|c|c|c|c|c|c|c|c|c|c|c|c|c|c|c|}
\hline & $\mathbf{N}$ & $\mathbf{P}$ & $\mathbf{K}$ & $\mathrm{Ca}$ & $\mathrm{Mg}$ & $\mathrm{S}$ & $\mathrm{Na}$ & $\mathrm{Cl}$ & $\mathrm{Cu}$ & $\mathrm{Zn}$ & Fe & Mn & $\mathrm{Pb}$ & $\mathbf{N i}$ & Co \\
\hline $\mathrm{N}$ & 1 & & & & & & & & & & & & & & \\
\hline $\mathrm{P}$ & $0.761 * *$ & 1 & & & & & & & & & & & & & \\
\hline K & $0.813^{* *}$ & $0.879 * *$ & 1 & & & & & & & & & & & & \\
\hline $\mathrm{Ca}$ & 0.404 & 0.032 & -0.096 & 1 & & & & & & & & & & & \\
\hline $\mathrm{Mg}$ & $0.779 * *$ & 0.484 * & 0.401 & $0.674^{* *}$ & 1 & & & & & & & & & & \\
\hline $\mathrm{S}$ & -0.433 * & 0.078 & -0.118 & -0.354 & -0.251 & 1 & & & & & & & & & \\
\hline $\mathrm{Na}$ & $-0.718^{* *}$ & $-0.685^{* *}$ & $-0.761^{* *}$ & -0.249 & -0.400 & 0.375 & 1 & & & & & & & & \\
\hline $\mathrm{Cl}$ & $0.413^{*}$ & 0.158 & 0.013 & $0.851^{* *}$ & $0.781 * *$ & 0.016 & -0.127 & 1 & & & & & & & \\
\hline $\mathrm{Cu}$ & $0.599 * *$ & $0.685^{* *}$ & $0.673^{* *}$ & -0.245 & $0.444 *$ & 0.119 & -0.175 & 0.094 & 1 & & & & & & \\
\hline $\mathrm{Zn}$ & $0.856^{* *}$ & $0.763^{* *}$ & $0.709^{* *}$ & 0.399 & $0.819^{* *}$ & 0.006 & $-0.450 *$ & $0.643^{* *}$ & $0.728^{* *}$ & 1 & & & & & \\
\hline $\mathrm{Fe}$ & $0.577^{* *}$ & 0.257 & 0.057 & $0.829 * *$ & $0.855^{* *}$ & -0.265 & -0.191 & $0.808^{* *}$ & 0.190 & $0.614^{* *}$ & 1 & & & & \\
\hline Mn & 0.230 & -0.010 & -0.157 & $0.543^{* *}$ & $0.515^{* *}$ & -0.164 & -0.083 & 0.491 * & -0.055 & 0.228 & $0.742^{* *}$ & 1 & & & \\
\hline $\mathrm{Pb}$ & 0.199 & 0.093 & -0.068 & 0.339 & 0.299 & -0.082 & -0.056 & 0.284 & 0.035 & 0.205 & $0.539 * *$ & $0.706^{* *}$ & 1 & & \\
\hline $\mathrm{Ni}$ & -0.388 & -0.300 & -0.203 & $-0.650 * *$ & $-0.589 * *$ & -0.236 & 0.142 & $-0.869 * *$ & -0.157 & $-0.701 * *$ & $-0.532 * *$ & -0.220 & -0.180 & 1 & \\
\hline Co & -0.028 & 0.018 & -0.081 & -0.152 & -0.021 & -0.236 & -0.172 & -0.340 & -0.027 & -0.292 & 0.109 & 0.378 & 0.194 & $0.667 * *$ & 1 \\
\hline
\end{tabular}

** Correlation is significant at the 0.01 level (two-tailed). ${ }^{*}$ Correlation is significant at the 0.05 level (two-tailed). 


\section{Conclusions}

The results obtained in this study show that irrigation with TW is more advantageous than irrigation with (high saline) WW. Plant nutrient content was not adversely affected by irrigation with TW compared to irrigation with WW. Similarly, soil analysis showed no significant deterioration in soil physiochemical characteristics as a result of irrigation with TW. Based on these results, the use of irrigation with TW in the production of alfalfa can be recommended. However, further research is needed to approve the safety of using TW to irrigate other forage crops, considering the possible variations between sites in terms of TW quality and soil status. Even for alfalfa, research on the long-term effects needs to be performed as the current study is based only on results from 2 years.

Author Contributions: Conceptualization, W.S.; Formal analysis, M.K.O. and A.A.A.-G.; Funding acquisition, W.S.; Investigation, W.S.; Methodology, W.S.; Writing—original draft, W.S.; Writing—review \& editing, M.K.O. and A.A.A.-G.

Funding: This research was funded by the Deanship of Scientific Research, King Saud University, through the research group project number RG-1440-126.

Acknowledgments: The authors extend their appreciation to the Deanship of Scientific Research at King Saud University for funding this work through research group No. RG-1440-126. The authors also thank the Deanship of Scientific Research and RSSU at King Saud University for their technical support.

Conflicts of Interest: The authors declare no conflict of interest.

\section{References}

1. Scott, C.A.; Faruqui, N.I.; Raschid-Sally, L. Wastewater Use in Irrigated Agriculture: Confronting the Livelihood and Environmental Realities; CABI: Wallingford, UK, 2004.

2. Gatto D'andrea, M.L.; Salas Barboza, A.G.J.; Garces, V.; Rodriguez Alvarez, M.S.; Iribarnegaray, M.A.; Liberal, V.I.; Fasciolo, G.E.; van Lier, J.B.; Seghezzo, L. The Use of (Treated) Domestic Wastewater for Irrigation: Current Situation and Future Challenges. Int. J. Water Wastewater Treat. 2015, 1, 1-10.

3. Misra, A.K. Climate change and challenges of water and food security. Int. J. Sustain. Built Environ. 2014, 3, 153-165. [CrossRef]

4. Gosain, A.K.; Rao, S.; Basuray, D. Climate change impact assessment on hydrology of Indian river basins. Curr. Sci. 2006, 90, 346-353.

5. Bixio, D.; Cikurel, H.; Muston, M.; Miska, V.; Joksimovic, D.; Schäfer, A.; Ravazzini, A.; Aharoni, A.; Savic, D.; Thoeye, C. Municipal wastewater reclamation: Where do we stand? An overview of treatment technology and management practice. Water Sci. Technol. Water Supply 2005, 5, 77-85. [CrossRef]

6. Jiménez, B.; Asano, T. Water Reuse: An International Survey of Current Practice, Issues and Needs; IWA: London, UK, 2008.

7. Mateo-Sagasta, J.; Medlicott, K.; Qadir, M.; Raschid-Sally, L.; Drechsel, P. Proceedings of the UN-Water Project on the Safe Use of Wastewater in Agriculture; UNW-DPC: Bonn, Germany, 2013.

8. Aljaloud, A. Reuse of wastewater for irrigation in Saudi Arabia and its effect on soil and plant. In Proceedings of the 19th World Congress of Soil Science, Soil Solutions for a Changing World, Brisbane, Australia, 1-6 August 2010; pp. 1-6.

9. Al-A'ama, M.S.; Nakhla, G.F. Wastewater reuse in Jubail, Saudi Arabia. Water Res. 1995, 29, $1579-1584$. [CrossRef]

10. Malki, M.; Bouchaou, L.; Mansir, I.; Benlouali, H.; Nghira, A.; Choukr-Allah, R. Wastewater treatment and reuse for irrigation as alternative resource for water safeguarding in Souss-Massa region, Morocco. Eur. Water 2017, 59, 365-371.

11. Chávez, A.; Rodas, K.; Prado, B.; Thompson, R.; Jiménez, B. An evaluation of the effects of changing wastewater irrigation regime for the production of alfalfa (Medicago sativa). Agric. Water Manag. 2012, 113, 76-84. [CrossRef]

12. Hamilton, A.J.; Stagnitti, F.; Xiong, X.; Kreidl, S.L.; Benke, K.K.; Maher, P. Wastewater irrigation: The state of play. Vadose Zone J. 2007, 6, 823-840. [CrossRef]

13. Toze, S. Reuse of effluent water-Benefits and risks. Agric. Water Manag. 2006, 80, 147-159. [CrossRef] 
14. Muyen, Z.; Moore, G.A.; Wrigley, R.J. Soil salinity and sodicity effects of wastewater irrigation in South East Australia. Agric. Water Manag. 2011, 99, 33-41. [CrossRef]

15. Pereira, B.F.F.; He, Z.L.; Stoffella, P.J.; Melfi, A.J. Reclaimed wastewater: Effects on citrus nutrition. Agric. Water Manag. 2011, 98, 1828-1833. [CrossRef]

16. Gibson, R.; Durán-Álvarez, J.C.; Estrada, K.L.; Chávez, A.; Jiménez Cisneros, B. Accumulation and leaching potential of some pharmaceuticals and potential endocrine disruptors in soils irrigated with wastewater in the Tula Valley, Mexico. Chemosphere 2010, 81, 1437-1445. [CrossRef] [PubMed]

17. Muller, K.; Duwig, C.; Prado, B.; Siebe, C.; Hidalgo, C.; Etchevers, J. Impact of long-term wastewater irrigation on sorption and transport of atrazine in Mexican agricultural soils. J. Environ. Sci. Health B 2012, 47, 30-41. [CrossRef] [PubMed]

18. FAO. FAO Statistical Pocketbook; Food and Agriculture Organization of the United Nations: Rome, Italy, 2015.

19. Lloveras, J. Alfalfa (Medicago sativa L.) Management for Irrigated Mediterranean Conditions: The Case of the Ebro Valley; Reunion Eucarpiol du Groupe Medicago spp.: Zaragoza, Spain; Lieida, Spain, 2001; Volume 12, pp. 115-125.

20. Toze, S. Water reuse and health risks—Real vs. perceived. Desalination 2006, 187, 41-51. [CrossRef]

21. Buechler, S.; Mekala, G.D.; Keraita, B.; Van Veenhuizen, R. Wastewater use for urban and peri-urban agriculture. Urban Agric. Mag. 2006, 8, 243-273.

22. Ouedraogo, B. Perceptions of Ouagadougou market gardeners on water, hygiene and disease. Urban Agric. Mag. 2002, 8, 24-25.

23. Adrover, M.; Moyà, G.; Vadell, J. Seasonal and depth variation of soil chemical and biological properties in alfalfa crops irrigated with treated wastewater and saline groundwater. Geoderma 2017, 286, 54-63. [CrossRef]

24. Helalia, A.M.; Al-Tapir, O.A.; Al-Nabulsi, Y.A. The influence of irrigation water salinity and fertilizer management on the yield of Alfalfa (Medicago sativa L.). Agric. Water Manag. 1996, 31, 105-114. [CrossRef]

25. Kim, A.; van der Beek, H. A Holistic Assessment of the Water-for-Agriculture Dilemma in the Kingdom of Saudi Arabia. CIRS Occas. Pap. 2018, 19, 1-44.

26. Dikinya, O.; Areola, O. Comparative analysis of heavy metal concentration in secondary treated wastewater irrigated soils cultivated by different crops. Int. J. Environ. Sci. Technol. 2010, 7, 337-346. [CrossRef]

27. Leonard, R.; Mankad, A.; Alexander, K. Predicting support and likelihood of protest in relation to the use of treated stormwater with managed aquifer recharge for potable and non-potable purposes. J. Clean. Prod. 2015, 92, 248-256. [CrossRef]

28. Makropoulos, C.; Rozos, E.; Tsoukalas, I.; Plevri, A.; Karakatsanis, G.; Karagiannidis, L.; Makri, E.; Lioumis, C.; Noutsopoulos, C.; Mamais, D.; et al. Sewer-mining: A water reuse option supporting circular economy, public service provision and entrepreneurship. J. Environ. Manag. 2018, 216, 285-298. [CrossRef] [PubMed]

29. Mohammad, M.J.; Ayadi, M. Forage Yield and Nutrient Uptake as Influenced by Secondary Treated Wastewater. J. Plant Nutr. 2004, 27, 351-365. [CrossRef]

30. Leal, R.M.P.; Firme, L.P.; Montes, C.R.; Melfi, A.J.; Piedade, S.M.D.S. Soil exchangeable cations, sugarcane production and nutrient uptake after wastewater irrigation. Sci. Agric. 2009, 66, 242-249. [CrossRef]

31. Hussain, A.; Priyadarshi, M.; Dubey, S. Experimental study on accumulation of heavy metals in vegetables irrigated with treated wastewater. Appl. Water Sci. 2019, 9, 122. [CrossRef]

32. Fahmi, A.H.; Samsuri, A.W.; Jol, H.; Singh, D. Bioavailability and leaching of Cd and Pb from contaminated soil amended with different sizes of biochar. R. Soc. Open Sci. 2018, 5, 181328. [CrossRef] [PubMed]

33. Sahito, O.M.; Kazi, T.G.; Afridi, H.I.; Baig, J.A.; Talpur, F.N.; Baloch, S.; Memon, N.S.; Kori, N.G. Assessment of Toxic Metal Uptake by Different Vegetables Grown on Soils Amended with Poultry Waste: Risk Assessment. Water Air Soil Pollut. 2016, 227, 423. [CrossRef]

34. Julier, B.; Huyghe, C.; Ecalle, C. Within- and Among-Cultivar Genetic Variation in Alfalfa: Forage Quality, Morphology, and Yield. Crop Sci. 2000, 40, 365-369. [CrossRef]

35. Grewal, H.S.; Williams, R. Liming and Cultivars Affect Root Growth, Nodulation, Leaf to Stem Ratio, Herbage Yield, and Elemental Composition of Alfalfa on an Acid Soil. J. Plant Nutr. 2003, 26, 1683-1696. [CrossRef]

36. James, D.W.; Hurst, C.J.; Tindall, T.A. Alfalfa cultivar response to phosphorus and potassium deficiency: Elemental composition of the herbage. J. Plant Nutr. 1995, 18, 2447-2464. [CrossRef]

37. Mohammad Rusan, M.J.; Hinnawi, S.; Rousan, L. Long term effect of wastewater irrigation of forage crops on soil and plant quality parameters. Desalination 2007, 215, 143-152. [CrossRef] 
38. Siebe, C. Nutrient inputs to soils and their uptake by alfalfa through long-term irrigation with untreated sewage effluent in Mexico. Soil Use Manag. 1998, 14, 119-122. [CrossRef]

39. Brink, G.; Hall, M.; Shewmaker, G.; Undersander, D.; Martin, N.; Walgenbach, R. Changes in Alfalfa Yield and Nutritive Value within Individual Harvest Periods. Agron. J. 2010, 102, 1274-1282. [CrossRef]

40. Cornacchione, M.V.; Suarez, D.L. Emergence, Forage Production, and Ion Relations of Alfalfa in Response to Saline Waters. Crop Sci. 2015, 55, 444-457. [CrossRef]

41. Kiziloglu, F.M.; Turan, M.; Sahin, U.; Kuslu, Y.; Dursun, A. Effects of untreated and treated wastewater irrigation on some chemical properties of cauliflower (Brassica olerecea L. var. botrytis) and red cabbage (Brassica olerecea L. var. rubra) grown on calcareous soil in Turkey. Agric. Water Manag. 2008, 95, 716-724. [CrossRef]

42. Al-Karaki, G.N. Utilization of treated sewage wastewater for green forage production in a hydroponic system. Emir. J. Food Agric. 2011, 32, 80-94. [CrossRef]

43. Kalavrouziotis, I.K.; Koukoulakis, P.H.; Sakellariou-Makrantonaki, M.; Papanikolaou, C. Effects of treated municipal wastewater on the essential nutrient interactions in the plant of Brassica oleracea var. Italica. Desalination 2009, 242, 297-312. [CrossRef]

44. Bergmann, W. Nutritional Disorders of Plants: Development, Visual and Analytical Diagnosis, 3rd ed.; Fischer: Stuttgart, Germany, 1992; p. 741.

45. Elfanssi, S.; Ouazzani, N.; Mandi, L. Soil properties and agro-physiological responses of alfalfa (Medicago sativa L.) irrigated by treated domestic wastewater. Agric. Water Manag. 2018, 202, 231-240. [CrossRef]

46. Carter, L.J.; Williams, M.; Böttcher, C.; Kookana, R.S. Uptake of Pharmaceuticals Influences Plant Development and Affects Nutrient and Hormone Homeostases. Environ. Sci. Technol. 2015, 49, 12509-12518. [CrossRef] [PubMed]

47. Huang, J.W.; Grunes, D.L.; Kochian, L.V. Voltage-dependent $\mathrm{Ca}^{2+}$ influx into right-side-out plasma membrane vesicles isolated from wheat roots: Characterization of a putative $\mathrm{Ca}^{2+}$ channel. Proc. Natl. Acad. Sci. USA 1994, 91, 3473. [CrossRef] [PubMed]

48. Andrejauskas, E.; Hertel, R.; Marme, D. Specific binding of the calcium antagonist [3H]verapamil to membrane fractions from plants. J. Biol. Chem. 1985, 260, 5411-5414. [PubMed]

49. Wong, Y.S.; Lan, C.Y.; Chen, G.Z.; Li, S.H.; Chen, X.R.; Liu, Z.P.; Tam, N.F.Y. Effect of wastewater discharge on nutrient contamination of mangrove soils and plants. In Proceedings of the Asia-Pacific Symposium on Mangrove Ecosystems, Dordrecht, The Netherlands, 1-3 September 1995; pp. 243-254.

50. Dražić, G.; Mihailović, N.; Stojanović, Z. Cadmium Toxicity: The effect on Macro- and Micro-Nutrient Contents in Soybean Seedlings. Biol. Plant. 2004, 48, 605-607. [CrossRef] 